\title{
Editorial
}

\section{Skills through History}

Few historians would deny that skills are at the heart of modern medicine. Yet skill can prove troublesome to define. The content of what counts as a medical skill ranges widely across different dimensions of the body and self, as through places, disciplines and phases of history. From the physician's touch in physical examination to the discriminating eye of the histologist, from empathy in nursing to precision in surgery: all suppose and reproduce a skilled practitioner. Despite or perhaps because of their abundance, skills have appeared too easily as a self-evident feature of medical history. Their ubiquity and the wide spectrum of concepts they assimilate have obstructed efforts to historicise them, or to explore the wider implications of their transience. Impossible to deny and yet notoriously hard to define, skills in medical history are everywhere and nowhere at once, persistent through its sources and yet rare as organising principles of its scholarship. ${ }^{1}$ The object of this volume is to address that asymmetry, and begin unsettling the self-evidence of skills by drawing them into critical focus.

This brief introduction sets out to foreground existing work in the history of medical and scientific skill, and to emphasise the richness of the topic. Our claim, however, is not that skills have been absent in medical historiography. On the contrary, they arise again and again, and often in ways that are consistent with the perspective advocated here. Historians have asked how the evaluation of skills was closely bound up with professional aims, for instance, or how new diagnostic methods invented and relied on new skills. ${ }^{2}$ They have described how skills were transmitted through pedagogical practices ${ }^{3}$ and how medical specialisation was connected (or not) to the proliferation of medical skillsets. ${ }^{4}$ Despite these efforts, the category of skill itself is still easily taken for granted. A closer examination promises to cast light on the varied and refined practices that skills include, and to strengthen the connections of medical history to other fields, such as the history of observation, objectivity, emotions and the senses.

Although the focus of this special issue will be on the last two centuries, work on skill is of course not restricted to this period. Obvious fields for examining its history are surgery and anatomy, both of which underwent regime changes in the Middle Ages and

\footnotetext{
${ }^{1}$ Lorraine Daston, 'On Scientific Observation', Isis, 99, 1 (2008), 97-110.

2 Malcolm Nicolson, 'The introduction of percussion and stethoscopy to early nineteenth-century Edinburgh', in William F. Bynum and Roy Porter (eds), Medicine and the Five Senses (Cambridge: Cambridge University Press, 1993), 134-53; Susan C. Lawrence, 'Educating the senses: students, teachers and medical rhetoric in eigtheenth-century London', in William F. Bynum and Roy Porter (eds), Medicine and the Five Senses (Cambridge: Cambridge University Press, 1993), 154-78; Christopher W. Crenner 'Introduction of the Blood Pressure Cuff into US Medical Practice: Technology and Skilled Practice', Annals of Internal Medicine, 128, 6 (1998), 488-93; Warwick Anderson, 'The Reasoning of the Strongest: The Polemics of Skill and Science in Medical Diagnosis', Social Studies of Science, 22, 4 (1992), 653-84.

${ }^{3}$ Most commonly in studies of medical education, such as Kenneth M. Ludmerer, Learning to Heal. The Development of American Medical Education (New York: Basic Books, 1983).

${ }^{4}$ George Weisz, Divide and Conquer: A Comparative History of Medical Specialization (Oxford: Oxford University Press, 2006); Rosemary Stevens, American Medicine and the Public Interest. A History of Specialization, updated edition with a new introduction (Berkeley: University of California Press, 1998).
} 
early modern period..$^{5}$ Discussions of skill have been shown to have played a major role when the adherence to textual authorities was loosened and skills travelled between artistic and scientific worlds, and when craft knowledge took on a new significance in scientific endeavours. ${ }^{6}$ The topic of skill has also been relevant to discussions of European medicine of the late eighteenth century, when diseases were classified on the subjective feelings of patients (their 'symptoms'), and sorted into classes, orders, genera and species, in the manner of botanical classification. ${ }^{7}$ Thomas Sydenham, the English physician and father of classificatory medicine, noted his debt to the ancients for teaching skill in therapeutics. ${ }^{8}$ For him, the Hippocratic texts stressed the primacy of observation untinged by distorting hypotheses: the correct natural classification of disease demanded an astute observer armed with a lucid mind. Sydenham and others modelled their art of observation on the Hippocratic authority, but also on botany and painting. Hence in the classificatory tradition the faithful transcription of all minute elements of a disease should proceed 'in imitation of the exquisite industry of those painters who represent in their portraits the smallest moles and the faintest spots. ${ }^{9}$

Historians found in the break from classificatory medicine an opportunity to show how through disciplined investigation skilled practitioners came to generate and stabilise new objects of medical inquiry and intervention. ${ }^{10}$ Michel Foucault's famous concept of 'the clinical gaze' evoked this broader system of changes, and also the relevance of skills to medical history. When, in late 1816, René Laennec applied a rolled-up paper notebook to the chest of a patient, he conceived of a skilled means to access the internal phenomena of bodies, a technique crucial to the wider localisation of disease that continued throughout the nineteenth century. ${ }^{11}$ The clinical gaze he helped establish was that of a physician backed by an institution, enrolled in new orders of knowledge and discipline; it sought colour, depth and variation beyond horizontal taxonomies of eighteenth century, and strove to calculate the chances survival and suffering. ${ }^{12}$ Foucault's The Birth of the Clinic captured the intrinsic interconnectedness between new ways of knowing (and skilled) subjects and the identity of disease, calling forth the provocative circularity between the skilled diagnostician and the pathological body, a mutually constitutive relation seized on by many medical historians and sociologists since Foucault. ${ }^{13}$

\footnotetext{
5 See, for example, Michael McVaugh, 'Cataracts and Hernias: Aspects of Surgical Practice in the Fourteenth Century', Medical History, 45 (2001), 319-40; Andrew Cunningham, The Anatomist Anatomis'd. An Experimental Discipline in Enlightenment Europe (Farnham: Ashgate, 2010).

${ }^{6}$ See, for example, Pamela Smith, The Body of the Artisan. Art and Experience in the Scientific Revolution (Chicago: University of Chicago Press, 2004); for a survey, see also Steven Shapin, The Scientific Revolution (Chicago: University of Chicago Press, 1996).

7 Jacalyn Duffin, To See with a Better Eye: A Life of R. T. H. Laennec (Princeton, NJ: Princeton University Press, 1998), 27.

8 'Preface to the third edition', in Thomas Sydenham, The Works of Thomas Sydenham, vol. 1, R. G. Latham (trans.) (Birmingham, Alabama: The Classics of Medicine Library, 1979), 11.

${ }^{9}$ Ibid., 14 .

${ }^{10}$ For a discussion of the patient as an object of medical intervention, see Flurin Condrau, 'The Patient's View Meets the Clinical Gaze', Social History of Medicine, 20, 3 (2007), 525-40.

${ }^{11}$ Duffin, op. cit. (note 7), 121-50.

12 Michel Foucault, The Birth of the Clinic: An Archeology of Medical Perception, A. M. Sheridan (trans.) (London: Routledge, 1989), 109.

${ }^{13}$ See, for example, Ludmilla Jordanova, 'Social construction of medical knowledge', in Charles E. Rosenberg and Janet Golden (eds), Framing Disease: Studies in Cultural History (New Brunswick, NJ: Rutgers University Press, 1992); Thomas Schlich, 'Changing Disease Identities: Cretinism, Politics and Surgery (1844-92)', Medical History, 38 (1994), 421-43; Steven J. Peitzman, 'From Dropsy to Bright's Disease to End-Stage Renal Disease', Milbank Quarterly, 67, Supplement 1, (1989), 16-32; Adrian Wilson, 'On the History of DiseaseConcepts: The Case of Pleurisy', History of Science, 38 (2000), 271-82.
} 
To take just one example, in his study of microscopic anatomy in Edinburgh during the 1830s, Stephen Jacyna has described the debates surrounding the introduction of microscopes, showing how the development of the field of histology depended upon a disciplinary regulation of vision and its verbal expression. ${ }^{14}$ As Jacyna explains: 'The acquisition of technical competences was the precondition for participation in a shared morality.' Practitioners were both active, in that they prepared their own slides and made their own observations, but also 'docile ... in as much as strict control was exercised over what counted as a competent microscopic performance and what constituted a true observation'. ${ }^{15}$ The new microscopists learnt to see with what Jacyna called 'a skilled eye', regulated vision that combined technical competence with disciplined judgement. As in the case of diagnostic and therapeutic techniques, the trustworthiness of the microscope required a studied cultivation of the senses, and the development of a particular capacity for sound judgement. ${ }^{16}$ But the cultivation of a skilled experimenter was not the only solution to the emergent problems of vision during the nineteenth century. Skill proved to be historically interesting in other ways too, not least in connection to the assimilation of data in medical research. In their recent account of the history of objectivity, Lorraine Daston and Peter Galison have noted instances in which the skill of the knowledgeable observer threatened to corrupt neutral observation, in which skill posed an obstacle to successful experimentation. ${ }^{17}$ They cite the French physiologist Claude Bernard, who advocated the use of untrained assistants for the collection of experimental data in an attempt to co-opt the passive senses of an unbiased observer. ${ }^{18}$

The examples of observation and diagnosis, and in particular the detection of new phenomena, lead into another dimension of the history of skill pertaining to more recent work on experimental replication. The 'experimenter's regress', as the sociologist Harry Collins calls it, denotes a problem whereby experimenters' knowledge of the existence of certain phenomena depends on the accuracy of an apparatus used for its detection. Since the only way to determine the effectiveness of the apparatus is through the detection (or not) of the phenomenon, scientists confront a circularity whereby the existence of a phenomenon is only ascertainable by an experimental apparatus whose status is in question. In such cases, the correctness of an experimental result and the associated claims about nature become entangled with claims about the credibility and skill of the experimenter. ${ }^{19}$ Such quandaries have been as real to medicine as to science - for instance,

${ }^{14}$ L. S. Jacyna, “A Host of Experienced Microscopists”: The Establishment of Histology in Nineteenth-Century Edinburgh', Bulletin of the History of Medicine, 75, 2 (2001).

15 Jacyna, op. cit. (note 14), 240, emphasis in original. On docile bodies, see Michel Foucault, Discipline and Punish: The Birth of the Prison (Alan Sheridan trans.) (London: Harmondsworth, 1977); Jonathan Crary, Techniques of the Observer (Cambridge, MA: MIT Press, 1990), 16; Ian Hacking, Representing and Intervening: Introductory Topics in the Philosophy of Natural Science (Cambridge: Cambridge University Press, 1983), 186209.

16 Skilled vision in science and medicine has been the topic of a number of historical investigations, for example: Jutta Schickore, The Microscope and the Eye: A History of Reflections, 1740-1870 (Chicago: University of Chicago Press, 2007). For microphotography, see Thomas Schlich, 'Linking Cause and Disease in the Laboratory: Robert Koch's Method of Superimposing Visual and "Functional" Representations of Bacteria', History and Philosophy of the Life Sciences, 22 (2000), 71-88. See also the essays in Nancy Anderson and Michael R. Dietrich (eds), The Educated Eye. Visual Culture and Pedagogy in the Life Sciences (Hanover, NH: Dartmouth College Press, 2012).

${ }^{17}$ Lorraine Daston and Peter Galison, Objectivity (Chicago: Zone Books, 2008), 341-2.

18 This was not a solution exclusive to Bernard or indeed to the history of experimental medicine. On the topic of unskilled workers and nuclear photography in the 1940s, see Peter Galison, Image and Logic: A Material Culture of Microphysics (Chicago: University of Chicago Press, 1997).

${ }^{19}$ Harry Collins, Changing Order: Replication and Induction in Scientific Practice (Chicago: University of Chicago Press, 1992), 83-4. 
in the introduction of new diagnostic methods (such as the stethoscope in the nineteenth century, or X-rays in the early twentieth) where questions of a physicians' skill played a decisive role in the adoption and spread of the new technologies. ${ }^{20}$

These disputes raise further questions, such as what it is that allows or restricts a skilful performance, or, more profoundly, what phenomena the concept of 'skill' can legitimately include. In the history of science, a skilful performance has often been connected to particular affective regimes, typically involving self-control, emotional restraint and the tempering of passions. ${ }^{21}$ The history of medicine offers similar examples. At one extreme is the cultivated indifference of the modern physician, who wields disinterest in the face of adversity and human suffering, a detachment founded historically on a contrast between emotional excess, which is seen to interfere with skill, and emotional restraint, which enables it. In the domain of emotional restraint it is the surgeon who is undisputed master, as attested to in a wealth of historical and ethnographic studies that have scrutinised the evolution of surgical decorum. ${ }^{22}$ When in 1912 Sigmund Freud recommended 'emotional coldness' for physicians practising psychoanalysis, he too cited the example of the surgeon who 'puts aside all his feeling, even his human sympathy, and concentrates his mental forces on the single aim of performing the operation as skilfully as possible'. ${ }^{23}$ Yet at another extreme is the status of emotion itself - that is, emotionality as skill. In a recent essay, the historian Elizabeth Lunbeck has noted the controversial proposals of Heinz Kohut, the prominent psychoanalyst and champion of empathy in psychoanalytic practice, who in the mid-twentieth century called into question the received antagonism between skill and emotionality. Untroubled by its impressionistic burdens, Kohut presented empathy not only as a tool of empirical science but also as a psychoanalytic strategy vital for the apprehension of inner experience. Lunbeck notes that much of the sustained controversy around Kohut's idea was skill's nebulous content, and whether or not emotions could plausibly count as skilful. ${ }^{24}$ Historically speaking, the answer came back as a resounding 'yes' - and not just among psychoanalysts. The

${ }^{20}$ Jens Lachmund, Der Abgehorchte Körper. Zur historischen Soziologie der medizinischen Untersuchung (Opladen: Westdeutscher Verlag, 1997); Bernike Pasveer, 'Knowledge of the Shadows: The Introduction of XRay Images in Medicine', Sociology of Health and Illness, 11, 4 (1989), 360-81. Similar arguments about skills have also been found to be powerful in discussions of the viability of new therapies, for example in surgery: Thomas Schlich, Surgery, Science and Industry: A Revolution in Fracture Care, 1950s-1990s (Basingstoke: Palgrave, 2002).

${ }^{21}$ Barbara Rosenwein, 'Worrying about the Emotions', American Historical Review, 107, 3 (2002), 821-45; Paul White, 'Introduction', Isis, 100, 4 (2009), 811-26.

22 Linda Payne, With Words and Knives: Learning Medical Dispassion in Early Modern England (Ashgate, 2007); Peter Stanley, For Fear of Pain: British Surgery, 1790-1850 (Amsterdam and New York: Editions Rodopi, 2003); Christopher Lawrence, 'Medical minds, surgical bodies: corporeality and the doctors', in Christopher Lawrence and Steven Shapin (eds), Science Incarnate: Historical Embodiments of Natural Knowledge (Chicago: University of Chicago Press, 1998), 156-201; Rachel Prentice, Bodies in Formation: An Ethnography of Anatomy and Surgery Education (Durham, NC: Duke University Press, 2013), 131-96; Delia Gavrus, 'Men of Strong Opinions: Identity, Self-Representation and the Performance of Neurosurgery' (unpublished PhD thesis: University of Toronto, 2011). See also Roger Kneebone and Abigail Woods, 'Recapturing the History of Surgical Practice through Simulation-based Re-enactment', Medical History, 58 (2014), 106-21, 109; and the contributions of Delia Gavrus and Thomas Schlich to this special issue.

${ }^{23}$ Sigmund Freud, 'Recommendations to Physicians Practising Psycho-Analysis (1912)', in The Standard Edition of the Complete Psychological Works of Sigmund Freud, volume 12, James Strachey (trans.) (London: Hogarth Press and the Institute of Psychoanalysis, 1958), 115. See also Elizabeth Lunbeck, 'Empathy as a psychoanalytic mode of observation: between sentiment and science', in Lorraine Daston and Elizabeth Lunbeck (eds), Histories of Scientific Observation (Chicago: University of Chicago Press, 2011), 255-75.

${ }^{24}$ Elizabeth Lunbeck, 'Empathy as a psychoanalytic mode of observation: between sentiment and science', in Daston and Lunbeck, op. cit. (note 23), 255-75. Also on the relations of the emotions to objectivity, see Paul White, 'Darwin's Emotions: The Scientific Self and the Sentiment of Objectivity', Isis, 100, 4 (2009), 811-26. 
inventory of skilled emotions widened exponentially with the birth and growth of bioethics in the later twentieth century, whose proponents have posited roll-calls of emotional and moral skills in pursuit of improved medical practice. ${ }^{25}$

The entanglement of skills and emotions of course pre-dates the rise of psychoanalysis or bioethics, and has a much older and well-documented association in the history of nursing. The title of the historian Susan Reverby's monograph, Ordered to Care: The Dilemma of American Nursing, 1850-1945, captures a persistent tension in this history between the realms of spontaneity and passion on the one hand, and reason and control on the other. Noting Florence Nightingale's definition of 'character as skill', Reverby examines the assertion that womanly attributes were a component of a nurse's ability to provide care during the nineteenth century. ${ }^{26}$ The sentiment was evident in Nightingale's missionary efforts to export her ideal of nursing to Australia, during which she specified class, gender and the moral authority of ladies as the major sources of 'nursing's power' 27 - a power that consisted in protecting the humanity of patients otherwise obscured by the therapeutic encounter. '[I]t is quite surprising how many men (some women do it too), practically behave as if the scientific end were the only one in view,' Nightingale remarked in her Notes on Nursing, 'as if the sick body were but a reservoir for stowing medicine into, and the surgical disease only a curious case the sufferer has made for the attendant's special information. ${ }^{28}$ The skilled nurse and woman was the antidote to such reductionist indifference; she alone could confer the status of patient and raise pathology into dignified suffering.

Yet Nightingale's positive appraisal of feminine virtues finds a counterpoint in debates about women's access to medical education of the same period. As women struggled to gain entry to the medical schools of Europe and North America in the nineteenth and early twentieth centuries, prominent opponents claimed that since femininity was bound by nature to empathy and compassion, its bearers were singularly unfitted for the trials of medical life. ${ }^{29}$ Feminist scholars have exposed the gendering of skill in this period as a political and exclusionary device, a weapon raised against women's access to medical education on the grounds of their 'natural' unsuitability. ${ }^{30}$ In both examples - skilled femininity as virtue and as vice - skill figures as an essential, inherent quality of a gendered self. Its naturalisation comes freighted with implications.

Such examples further raise the question of what skill in fact is - if not a natural, innate quality of people, what kind of knowledge does skill represent? It is in response

25 David Adams, "Artificial Kidneys and the Emergence of Bioethics: The History of "Outsiders" in the Allocation of Haemodialysis', Social History of Medicine, 24, 2 (2011), 461-77.

${ }^{26}$ Susan Reverby, Ordered to Care: The Dilemma of American Nursing, 1850-1945 (Cambridge: Cambridge University Press, 1987), 39-59. On emotional labour in the twentieth century, Arlie Russell Hochschild, The Managed Heart: Commercialization of Human Feeling, with a new afterword (Berkeley: University of California Press, 2003).

27 See Judith Godden and Carol Helmstadter, 'Woman's Mission and Professional Knowledge: Nightingale Nursing in Colonial Australia and Canada', Social History of Medicine, 17, 2 (2004), 157-74.

${ }^{28}$ Florence Nightingale, Notes on Nursing and Notes on Hospitals (Birmingham Alabama: Classics of Medicine Library, 1982), 70.

${ }^{29}$ There is a wealth of literature on this topic: Thomas N. Bonner, To the Ends of the Earth: Women's Search for Education in Medicine (Cambridge, MA: Harvard University Press, 1992); James Stuart Garner, 'The Great Experiment: The Admission of Women Students to St. Mary's Hospital Medical School', Medical History, 42 (1998), 68-88; Claire Brock, 'Surgical Controversy at the New Hospital for Women, 1872-92', Social History of Medicine, 24, 3 (2011), 608-23; Claire Brock, 'The fitness of the female medical student, 1895-1910', in Francesca Scott, Kate Scarth and Ji Won Chung (eds), Picturing Women's Health (London: Pickering and Chatto, 2014), 139-57.

${ }^{30}$ See Joan I. Roberts and Thetis M. Group, Nursing, Physician Control, and the Medical Monopoly (Bloomington: Indiana University Press, 2001). 
to this type of question that sociologists and historians began exploring the category of 'tacit knowledge' during the late 1970s and 1980s. A younger cousin to Gilbert Ryle's distinction of 'knowing how' and 'knowing that' (itself derived from phenomenological roots ${ }^{31}$ ), the distinction between explicit and tacit knowledge was first explored by the philosopher Michael Polanyi, and became of enduring inspiration for scholars of a later generation committed to the descriptive exploration of scientific, and later medical practices. ${ }^{32}$ Despite varying definitions, the tacit dimension became of indisputable heuristic value for the field of science studies in emphasising the face-to-face character of scientific work, and in dissipating a model of science as rule-bound and algorithmic. ${ }^{33}$ Medical historians borrowed the concept to similar ends, emphasising, for example, the embodied skills of surgeons, acquired through active and corporeal engagement rather than through explicit instruction. ${ }^{34}$

Yet despite the remarkable payoffs of the tacit dimension, some authors have warned of the essentialist pitfalls in the liberal use of an analyst's category, pointing out that tacit knowledge can be made explicit, ${ }^{35}$ or insisting that historians must contextualise actors' use of the concept, and pay attention to actors' vocabularies of skill, knowledge and learning. ${ }^{36}$ Polanyi's formulation was notably saturated in politics from the start, asserting the immunity of scientific research to external planning. ${ }^{37}$ Likewise, embedded in the recent efforts by Harry Collins and others to clarify tacit knowledge are normative questions of expertise in science and scientific medicine: who should be included as contributory experts and who not, by whose authority or on what grounds? ${ }^{38}$ Whatever the value of the tacit dimension in casting a light on science as a cultural activity, the history of the term itself demonstrates what can be at stake when skills and knowledge are scrutinised and divided.

\footnotetext{
${ }^{31}$ Gilbert Ryle, The Concept of Mind (London: Hutchinson, 1949). On the relationship of tacit and explicit knowledge to 'knowing how' and 'knowing that', see Neil Gascoigne and Tim Thornton, Tacit Knowledge (Durham: Acumen, 2013), 13-49.

32 On the sociological analysis of skills in medicine, see H. M. Collins, G. H. de Vries and W. E. Biker, 'Ways of Going On: An Analysis of Skill Applied to Medical Practice', Science, Technology \& Human Values, 22, 3 (1997), 267-85.

${ }^{33}$ Harry Collins, Changing Order: Replication and Induction in Scientific Practice (Chicago: Chicago University Press, 1985/92), 56-8; Harry Collins, Tacit and Explicit Knowledge (Chicago, London: University of Chicago Press, 2010).

34 Thomas Schlich, Surgery, Science and Industry: A Revolution in Fracture Care, 1950s-1990s (Basingstoke: Palgrave Macmillan, 2002); Sally Wilde, 'See One, Do One, Modify One: Prostate Surgery in the 1930s', Medical History, 48 (2004), 351-66; Trevor Pinch, H. M. Collins and Larry Carbone, 'Inside Knowledge: Second Order Measures of Skill', Sociological Review, 44, 2 (1996), 163-86; Christopher Lawrence, 'Medical minds, surgical bodies: corporeality and the doctors', in Christopher Lawrence and Steven Shapin (eds), Science Incarnate: Historical Embodiments of Natural Knowledge (Chicago: University of Chicago Press, 1998), 156-201.

35 Alberto Cambrosio and Peter Keating, Exquisite Specificity: The Monoclonal Antibody Revolution (Oxford: Oxford University Press, 1995), 45-79.

${ }^{36}$ Catherine Pope, 'Resisting Evidence: The Study of Evidence-Based Medicine as a Contemporary Social Movement', Health, 7 (2003), 267-82, 274-5.

37 The history is relayed in Adrian Johns, Piracy: The Intellectual Property Wars from Gutenberg to Gates (Chicago: University of Chicago Press, 2009), 415-22. See M. Polanyi, Personal Knowledge: Towards a Postcritical Philosophy (London: Routledge \& Kegan Paul, 1973, first published in 1958); M. Polanyi, 'The Planning of Science', Political Quarterly, 16 (1945), 316-28.

${ }^{38}$ See Harry M. Collins and Robert Evans. 'The Third Wave of Science Studies: Studies of Expertise and Experience', Social Studies of Science, 32, 2 (2002), 235-96; Harry Collins, Tacit and Explicit Knowledge (Chicago: University of Chicago Press, 2010). Similarly, the sociology of skill is also linked to clarifying differences between humans and machines; see Collins et al., op. cit (note 32); Harry Collins and Martin Kusch, The Shape of Actions: What Humans and Machines Can Do (Cambridge, MA: MIT Press, 1999).
} 
Similar political stakes are evident in the long-standing debates over the status of medicine as an 'art' or 'science'. ${ }^{39}$ Making medicine scientific has been an oftenused and successful strategy for increasing the influence and autonomy of the medical profession, and also for improving its practices. ${ }^{40}$ One means for turning medicine into a science was basing medical practice on the natural laws of body function determined by experimental science. This was Claude Bernard's programme of 'experimental medicine' of the nineteenth century, which looked to the laboratory to lend credence to the clinic. In the second half of the twentieth century, medical reformers went further and re-described the entirety of medical practice as scientific - 'every bit as scientific as the research laboratory ${ }^{41}$ - predicating their claims on the increasing standardisation of medical skills. Echoing the logic of experimental replication, they contended that the perfect reproducibility of therapeutic measures entailed the strict standardisation of every step of the therapeutic procedure. ${ }^{42}$ Yet such strategies did not go unchallenged. Opponents to standardisation feared that an exaggerated focus on science would undermine their professional autonomy in patient care, ${ }^{43}$ and presented medical practice as an inscrutable art, requiring diligence, experience and cultivated good judgement. ${ }^{44}$ They argued that standardisation would reduce medical treatment to mindless routine, performed by 'unthinking physicians'. Along these lines, Christopher Lawrence has shown how during the nineteenth century elite London physicians raised criticisms against the swelling tide of scientific medicine threatening to unhinge their claims to clinical autonomy. These physicians espoused the virtues of the cultivated gentleman, criticising undue dependence on new medical technologies and the growth of specialisation. For them the clinical art was a holistic, ineffable form of knowledge based on a broad education in the classics and long years of clinical experience, irreducible to a formalised body of information bound by precise rules. Echoing the prominent anatomist and surgeon William Bowman, Lawrence proposed the term incommunicable knowledge, 'an epistemology of individual experience which, by definition, defied analysis', and which assured the protection of clinical art from the rising frontier of applied science, as well as from the pedagogical claims of a new generation of scientific teachers. ${ }^{45}$ The trenchant defence of generalism in clinical practice - and later of 'holism'46 - asserted the insufficiency of technical skills for sound clinical practice, defined as something beyond the mere functionality of a skilled executor.

Typically, characterisations of medicine as an art or a science do not represent realistic descriptions of attainable goals but offer, as Warwick Anderson has emphasised,

\footnotetext{
39 Thomas Schlich, 'The Art and Science of Surgery: Innovation and Concepts of Medical Practice in Operative Fracture Care, 1960s-1970s', Science, Technology and Human Values, 32 (2007), 65-87.

40 The literature is wide-ranging. For an overview, see John Harley Warner, 'The History of Science and the Sciences of Medicine', Osiris, 10 (1995), 164-93.

${ }^{41}$ Harry M. Marks, The Progress of Experiment. Science and Therapeutic Reform in the United States, 1900-90 (Cambridge: Cambridge University Press, 1997), 2.

42 See Schlich, op. cit. (note 39), 74.

43 Stefan Timmermans and Marc Berg, The Gold Standard. The Challenge of Evidence-Based Medicine and Standardization in Health Care (Philadelphia: Temple University Press, 2003), 83-5.

${ }^{44}$ Marc Berg, 'Turning a Practice into a Science: Reconceptualizing Postwar Medical Practice', Social Studies of Science, 25 (1995), 437-76, 442; see also Steve Sturdy and Roger Cooter, 'Science, Scientific Management, and the Transformation of Medicine in Britain c. 1870-1950', History of Science, 36 (1998), 421-66, 435-9.

45 Christopher Lawrence, 'Incommunicable Knowledge: Science, Technology and the Clinical Art in Britain 1850-1914', Journal of Contemporary History, 20, 4 (1985), 503-20, 505.

46 On the persistence of this rhetoric into the first decades of the twentieth century, see Christopher Lawrence, 'Still incommunicable: clinical holists and medical knowledge in interwar Britain', in C. Lawrence and G. Weisz (eds), Greater than the Parts: Holism in Biomedicine, 1920-50 (New York: Oxford University Press), 94-111.
} 
'versatile discursive resources and strategies' for the pursuit or maintenance of professional hierarchies, authority and autonomy. ${ }^{47}$ Conceived of as an art, medicine emphasises personal authority. According to this model, the transmission of skill requires apprenticeship, spectatorship, and, as Michael Polanyi explained, submission to authority: 'You follow your master because you trust his manner of doing things even when you cannot analyse and account in detail for its effectiveness. ... These hidden rules can be assimilated only by a person who surrenders himself to that extent uncritically to the imitation of another. ${ }^{48}$ By contrast, the understanding of medicine as a science can support (among other things) a quite different, avowedly meritocratic epistemology: clinical skills become generally attainable; anyone adhering to the rules can achieve good results. ${ }^{49}$ The ideal of clinical science, Deborah Gordon writes, 'is characteristically explicit, universal, abstract and public'; ${ }^{50}$ it subordinates social privilege and upholds the accessibility of expertise. ${ }^{51}$

If such strict divisions are shown easily by historians to be crude and simplistic, they have nonetheless been persistent and consequential features in the rise of scientific medicine. A profound belief in the virtues of science was a central plank in early twentieth century doctrines of 'scientific management', developed by, among others, the American engineer, Frederick Winslow Taylor, who from the 1890s sought to reorganise labour processes according to rigidly scientific principles. ${ }^{52}$ In Taylor's thinking, skills could be measured, timed, quantified, and disassembled into elementary units, and then transferred to unskilled workers. Health care seemed to be an especially ripe candidate for such reform strategies. ${ }^{53}$ Between 1900 and 1920, tools from the world of business were imported to hospitals, ${ }^{54}$ newly conceived as 'workshops for physicians' or 'health factories', 55 while surgery, considered a species of manual labour, was amenable to the time-andmotion analysis of the engineer Frank Gilbreth, an advocate of scientific management who famously rejected any qualitative difference between motions across practical domains. ${ }^{56}$ The ramifications of this levelling epistemology were clear to such reformers as the Boston surgeon Ernest Amory Codman, ${ }^{57}$ who wished to promote objective criteria in health care, and to the orthopaedic surgeon Robert Jones, said to have 'never wasted a motion', who was responsible for reorganising and standardising orthopaedic care in Britain before and during the First World War. According to the historian Roger Cooter, Jones became a leading figure for a whole cohort of British surgeons committed to

47 Anderson, op. cit. (note 2), 677.

48 Polanyi, Personal Knowledge (note 37), 53.

49 G. Gigerenzer, Z. Swijtink, T. Porter, L. Daston, J. Beatty, and L. Krüger, The Empire of Chance: How Probability Changed Science and Everyday Life (Cambridge: Cambridge University Press, 1998), 265.

${ }^{50}$ Deborah Gordon, 'Clinical science and clinical expertise: changing boundaries between art and science in medicine', in M. Lock and D. Gordon (eds), Biomedicine Examined (Dordrecht: Kluwer), 259-60.

51 Theodore M. Porter, Trust in Numbers. The Pursuit of Objectivity in Science and Public Life (Princeton, NJ: Princeton University Press, 1995), 204.

52 Samuel Haber, Efficiency and Uplift: Scientific Management in the Progressive Era 1890-1920 (Chicago: University of Chicago Press 1964); Charles S. Maier, 'Between Taylorism and Technocracy: European Ideologies and the Vision of Industrial Productivity in the 1920s', Journal of Contemporary History, 5 (1970), $27-61$.

${ }^{53}$ Edward T. Morman, 'Introduction', in Edward T. Morman (ed.), Efficiency, Scientific Management, and Hospital Standardization (New York: Garland, 1989), i-xxvii, i.

54 Joel D. Howell, Technology in the Hospital. Transforming Patient Care in the Early Twentieth Century (Baltimore, MD: Johns Hopkins University Press, 1995), 65-6.

55 Susan Reverby, 'Stealing the Golden Eggs: Ernest Amory Codman and the Science and Management of Medicine', Bulletin for the History of Medicine, 55 (1981), 156-71, 157.

${ }^{56}$ Howell, op. cit. (note 54), 67.

${ }^{57}$ Reverby, op. cit. (note 55), 161-2. 
technical expertise, who campaigned for the adjudication of practitioners on grounds of efficiency and productivity. ${ }^{58}$ From 1914 , the Great War provided further occasion for introducing modern management techniques into military health care, both in British military medicine, for example, and also in Austria, where historians have described intense efforts at mobilising medical resources and economising manpower through the standardisation of medical practices. ${ }^{59}$

These are just some examples of how historians have approached the topic of skills in medical history. As they indicate skills' contingent status across time and through disciplines, they point further to the potentials of a history of skill, and suggest ties to related fields of inquiry such as the histories of objectivity and emotionality, the body and its senses.

\section{Historicising Skills}

The essays of this special issue comprise a selective collection aimed at establishing the thematic relevance of skills to history. In different ways, the authors examine how pathologists, bacteriologists, surgeons, nurses, chemists and genetic scientists of the nineteenth and early twentieth centuries confronted the question of skill across a range of contexts. They look at who claimed authority to participate in those struggles, and what was at stake in the determination, ascription, demonstration or denial of particular skillsets. The historian David Kaiser has noted through his reflections on the history of pedagogy, that within a given scientific field or specialty, "what counts as "appropriate skills", always reflects active decisions (and often fraught controversy and bitter negotiations) in given contexts, and show $[\mathrm{s}]$ telling variation across time and space' ${ }^{60}$ That variation is a starting point for this special issue. In exploring it further, we want to pursue the following kinds of question: When does skill become a salient or urgent focus for debate in medicine? How are skills defined and by what means? To whom or to what can skills be attributed or transferred? In what ways and in what contexts have skills been considered important, and who can claim the authority to define them? Is the presence of skill always considered a good thing, and, if not, on what grounds can a skilled activity be bad?

We are not to the first to raise such questions. Besides the work already noted, for other fields in history the definition of skill has been a central if not defining focus for analysis. Over the last four decades, labour historians have moved furthest in providing a critical history of skills, and have shown how such histories can proffer rich results. Much of this work has developed in response to Harry Braverman's widely influential study of 1974, Labor and Monopoly Capital: The Degradation of Work in the Twentieth Century, a seminal account of occupational changes to the American workforce during

\footnotetext{
58 Roger Cooter, Surgery and Society in Peace and War: Orthopaedics and the Organization of Modern Medicine, 1880-1948 (Houndmills, Basingstoke: Macmillan, 1993), 32, 47, 93, 113-4, 121.

${ }^{59}$ Roger Cooter and Steve Sturdy, 'Of war, medicine and modernity: introduction', in Roger Cooter, Mark Harrison and Steve Sturdy (eds), War, Medicine and Modernity (Stroud, UK: Sutton, 1998), 1-21, 3; Mark Harrison, 'Medicine and the Management of Modern Warfare', History of Science, 34 (1996), 379-410, 380; Mark Harrison, The Medical War: British Military Medicine in the First World War (Oxford: Oxford University Press, 2010); Thomas Schlich, 'The Perfect Machine: Lorenz Böhler's Rationalized Fracture Treatment in WWI', Isis, 100, 4 (2009), 758-91; Hans-Georg Hofer, 'Effizienzsteigerung und Affektdisziplin. Zum Verhältnis von Kriegspsychiatrie, Medizin und Moderne', in Petra Ernst, Sabine Haring and Werner Suppanz (eds), Aggression und Katharsis. Der Erste Weltkrieg im Diskurs der Moderne (Vienna: Passagen, 2004), 219-42, 228.

${ }^{60}$ David Kaiser, 'Introduction: moving pedagogy from the periphery to the center', in D. Kaiser (ed.), Pedagogy and the Practice of Science: Historical and Contemporary Perspectives (Cambridge, MA: MIT Press, 2005).
} 
the early twentieth century. ${ }^{61}$ Braverman, a factory worker turned Marxist historian, had become increasingly frustrated with the abstractions of his sociological peers, and sought an empirical alternative to the analysis of labour. Based on the study of occupational trends in the American workforce, he described a systematic process of 'deskilling': the increasing division of holistic craft traditions into atomised, narrowly conceived, and supposedly mindless tasks, and the gradual replacement of skilled activities by automation and machinery.

Labor and Monopoly Capital prompted a stream of critical debate, much of which focused on Braverman's important (though in fact not central) thesis of deskilling. ${ }^{62}$ Among the most interesting critiques were those which queried his definition of skill, and which doubted whether deskilling was truly a historical fact or merely an artefact of Braverman's own assumptions about the nature of skill. ${ }^{63}$ Central to this strand of critique was what has been called a 'strong current of constructionism', ${ }^{64}$ an approach to treating skills not as natural givens but as historically situated and therefore transient concepts. The recognition that "many ... skill distinctions are ... determined socially and historically', raised the question of who had hitherto defined skilled labour and what ends those definitions achieved. ${ }^{65}$ Feminist labour historians, for instance, began querying the political dynamics of skill, presenting it as a mechanism for imposing and sustaining gendered divisions of labour in nineteenth-century industries. Through case studies that traced the political and economic uses of notions of skill, they were able to show convincingly that '[f]ar from being an objective economic fact, skill is often an ideological category imposed on certain types of work by virtue of the sex and power of the workers who perform it' ${ }^{66}$ Common to such studies was a sustained interest in unpicking the consequences of the languages of skill. The deskilling debate, as well as the various processes it referred to - the automation of manual work, the specialisation of tasks and increasing divisions of labour, the use of efficiency as a gold standard, the compulsions of capital logic - can be seen as part of a critical expansion of what was understood as skill

\footnotetext{
${ }^{61}$ Harry Braverman, Labor and Monopoly Capital: The Degradation of Work in the Twentieth Century (New York: Monthly Review Press, 1975).

62 Scholars attacked Braverman on a variety of grounds, noting, for instance, that automation of particular duties tended not only replace the simplest tasks in a production process, but in many instances created new skilled roles in supervision and management. A useful review of these criticisms and others is Paul Attewell, 'The Deskilling Controversy', Work and Occupations, 14, 3 (1987), 323-46. See also, Craig R. Littler and Graeme Salaman, 'Bravermania and Beyond: Recent Theories of the Labour Process', Sociology, 16, 2 (1982), 251-69.

63 Among various criticisms, Braverman's detractors accused him of a selectivity of sources in both past and present. See Paul Attewell, 'The Clerk Deskilled: A Study in False Nostalgia', Journal of Historical Sociology, 2, 4 (1989), 357-88.

${ }^{64}$ Paul Attewell, 'What Is Skill?', Work and Occupations, 17, 4 (1990), 422-48, 440; Attewell, op. cit. (note 62), 323-46. For comparable discussions in the history of science and medicine, see Jan Golinski, Making Natural Knowledge: Constructivism and The History of Science (Chicago: University of Chicago Press, 2008); Ludmilla Jordanova, 'The Social Construction of Medical Knowledge', Social History of Medicine, 8, 3 (1995), 361-81; Ian Hacking, The Social Construction of What? (Cambridge, MA: Harvard University Press, 1999).

65 David Harvey, A Companion to Marx's Capital (London: Verso, 2010), 126.

66 Anne Phillips and Barbara Taylor, 'Sex and Skill: Notes towards a Feminist Economics', Feminist Review, 6 (1980), 79-88, 79; William Lazonick, Historical Origins of the Sex-based Division of Labour under Capitalism: A Study of the British Textile Industry during the Industrial Revolution (Cambridge, MA: Harvard Institute of Economic Research, Havard University, 1976); Sonya O. Rose, “Gender at Work”: Sex, Class and Industrial Capitalism', History Workshop Journal, 21 (1986), 113-32; William Lazonick, 'The Subjection of Labour to Capital: The Rise of the Capitalist System', Review of Radical Political Economics, 10, 1 (1978), 1-31, 19. Also on the alleged intrinsic limitations of gender on knowledge, see Alison Winter, 'A calculus of suffering: Ada Lovelace and the bodily constraints on women's knowledge in early Victorian England', in Christopher Lawrence and Steven Shapin (eds), Science Incarnate: Historical Embodiments of Natural Knowledge (Chicago: University of Chicago Press, 1998), 202-39.
} 
in the conceptual sense. It becomes clear in retrospect that the discussions on deskilling were as much about constructing the concept of skill as about lamenting its decline among labourers of late capitalism. Skills were not merely the object of critical investigation, they were also its product.

Focused on Anglo-American and European contexts of the recent past, the papers collected here are similarly committed to exploring the historical contingency of skill. In doing so, they seek to challenge some engrained assumptions common to its history, such as the belief that skill is an obviously desirable quality of workers. In her essay on the first generation of American neurosurgeons, Delia Gavrus describes the establishment of a specific ethical regime of professional practice, which entailed a tension between advanced levels of surgical skill and the moral integrity and trustworthiness of practitioners. The most dangerous surgeons, the new neurosurgeons contended, were those with skills in abundance, the maverick showmen whose excessive competence and theatrical tendencies imperilled both patient and specialty. Gavrus pays particular attention to the establishment of a distinctive social space, 'the specialist society', in which skills could be determined and evaluated, and by which entry into the elite world of neurosurgery could be regulated.

In his account of skill in modern surgery, Thomas Schlich likewise considers variations in meanings of surgical skill across the nineteenth and twentieth centuries, noting their entanglements with aesthetic categories of elegance, artistry and surgical style, but also with ethical standards of the time. He uses the notion of performance to look at changing evaluations of surgical skill and how they were predicated on the technical, professional, and moral contexts in which surgical work took place. The meaning of desirable skill in surgery underwent significant changes over the course of the nineteenth and early twentieth centuries, complicating any simplistic assumptions about the dependence of surgical work on manual skill.

Surgery is one example of how claims to skill can define boundaries between expert groups, thus steering and shaping professional identities. In her essay on the establishment of the specialty of neuropathology in postwar England, Kathryn Schoefert shows how another professional identity was associated with a particular definition of skill. The new specialty of neuropathology incorporated elements of microscopy, and was perched between neurology, psychiatry and neurosurgery. Yet as Schoefert demonstrates, the means available to neuropathologists for their self-definition were constrained by the institutional forces of the British National Health Service, as by the competing claims of neighbouring disciplines. Schoefert's analysis of a precarious medical specialty resonates not only with sociological accounts of boundary work, which stress the instrumental distinctions deployed by scientists to demarcate their practices, but also with studies that analyse how attributions of skill can serve specific institutional goals and interests.

The relationship of skills to standardisation is the theme of Nicholas Whitfield's analysis of the Carrel-Dakin wound treatment of the Great War, which he considers in relation to currents of standardisation, scientific medicine and theories of scientific management. Whitfield describes how, according to contemporary estimations, the Carrel-Dakin method increased rather than diminished demands on surgical skill, and that contemporary debates about antiseptic wound treatment opened up a critical space for considering the nature of skill as a defining feature of surgical practice. Whitfield contributes to accounts of standardisation in medical history by splitting them away from narratives of deskilling. The standardisation of wound treatment was not a moment at which skills vanished in the shadow of modernity and scientific medicine, but a point at which skill was figuratively expanded and drawn to the heart of surgical practice. 
Shifting from professions to pathologies, Susan Lamb's paper investigates skill in early twentieth-century Anglo-American psychiatry. Her focus is Adolf Meyer, the influential American psychiatrist, who in the decades prior to the First World War advocated a new set of clinical skills for what he termed 'the new psychiatry'. Looking in detail at Meyer's conception of 'psychobiology', a biological theory of mind and mental disorders, and at clinical practices and teaching at Johns Hopkins between 1913 and 1917, Lamb discusses how social and interpersonal skills became a vital means for Meyer to access, collect and analyse the ephemeral data of patients' social adaptations. Arguing that the social skills of the new psychiatrist were essential for constituting and treating patients according to the psychobiological approach, Lamb demonstrates the mutuality and co-dependence of clinical skills and pathologies.

In an essay that focuses on a controversy in the recent history of behaviour genetics, Nicole Nelson confronts the topic of experimental practice, and, in particular, the experimenter's regress. Her empirical focus is on new techniques for manipulating mouse DNA, developed in the 1990s, that allowed researchers to 'knock out' specific genes in mice in order to observe the behavioural effects. How to deploy these techniques became deeply controversial, and Nelson examines key methodological debates between a predominantly North American group of molecular biologists and animal behaviourists. She not only considers the overlaps of particular experimental facts about knock-out genes with judgements about who and what was generating them, but also shows how more substantive ideas of experimental skill were interwoven with the epistemologies of different knowledge-producing communities.

With their common orientation, these essays intend to expand and reposition skill as a fruitful focus for historical analysis and to highlight a broad range of avenues for future scholarship. Skills have a history - a long one - and though it is much wider than the present special issue could possibly encompass, we hope that the consciously historicist stance advocated here - skills through history - will challenge their presentation as stable qualities of medical practice, and cast further light on neighbouring areas of medical history whose tangled stories they intersect.

\section{NICHOLAS WHITFIELD, THOMAS SCHLICH}

Department of Social Studies of Medicine, McGill University, 3647 Peel Street, Montreal, Quebec, Canada H3A 1X1 Email: thomas.schlich@mcgill.ca 